\title{
An 112-Days Experiment on Dietary Cadmium Retention in Hepatopancreas in Adult Cantareus aspersus Snails
}

\author{
GEORGE A. DRAGHICl ${ }^{1}$, CRISTINA A. DEHELEAN ${ }^{1}$, IULIA PINZARU, DESPINA M. BORDEAN², GEORGETA POP², \\ DRAGOS V. NICA ${ }^{1}$ \\ IVictor Babes University of Medicine and Pharmacy, Faculty of Pharmacy, 2 Eftimie Murgu Sq., 300041, Timisoara, Romania \\ ${ }^{2}$ Banat University of Agricultural Sciences and Veterinary Medicine King Mihai I of Romania from Timisoara, Faculty of Food \\ Processing Technology, 119 Calea Aradului, 300645, Timisoara, Romania
}

\begin{abstract}
Cadmium is very hazardous pollutant with massive impact on aspects of everyday life. Little knowledge exists on kinetics of dietary cadmium retention in Cantareus aspersus for durations above three months although this species of land snails serves as excellent ecotoxicological model for studying cadmium hazard. Here was used a continuous 112-day exposure study design, in which test snails were exposed to a wide range of dietary cadmium levels, including human- and environmentally-relevantlevels. Using Flame Atomic Absorption Spectrometry, cadmium levels in the hepatopancreas were found to increase significantly, and in dose-dependent manner starting from a dietary cadmium dose of $0.2 \mathrm{mg} / \mathrm{kg}$ dry weight. The results of the present study render the hepatopancreas of mature snails, $C$. aspersus, as excellent endpoints for assessing $C d$ toxicity over a broad range of concentrations. Hence, this species of land snails can be reliably used for both active and passive biomonitoring of environmental cadmium pollution.
\end{abstract}

\section{Keywords: Cadmium, retention, Cantareus aspersus, dietary asperses}

Cadmium $(\mathrm{Cd})$ contamination in terrestrial environments is a major global issue; it increases year after year with a massive impact on everyday life ranging from ecological sustainability and food security to human health. This trace metal (TM) occurs naturally in the Earth' crust with an abundance of $0.1-0.5 \mathrm{mg} / \mathrm{kg}$ dry weight $(\mathrm{mg} / \mathrm{kg}$ d. wt) [1].

Cadmium is a very hazardous pollutant due to several key reasons, primarily the long biological half-life (10-30 years), high accumulation potential along the terrestrial food webs and high toxicity at levels one-tenth that of lead $(\mathrm{Pb})$, mercury $(\mathrm{Hg})$ or aluminum (Al) [2,3].

There is limited knowledge about the kinetics of cadmium retention in gastropod models exposed for longterm (> 3 months) to elevated levels of cadmium [4]. The hepatopancreas, which is the molluskan homologous organ for both the mammalian liver and pancreas, represents the primary endpoint of $\mathrm{Cd}$ retention. In this context, the present experiment aimed to determine the level of dietary Cd which led to an increase in Cd retention in the snail hepatopancreas. Was used a continuous 112day exposure, multiple dose study design using newlymatured Cantareus aspersus snails as invertebrate model. Hepatopancreas cadmium level was assessed using Flame Atomic Absorption Spectrometry.

\section{Experimental part}

Materials and Methods

The snails (Cantareus aspersus) were obtained in September 2018 from the Mokry Dwor farm (Krzymow, Wielkopolska, Poland) and transferred to a climatecontrolled room $\left(18-20^{\circ} \mathrm{C}, 12 \mathrm{~h} / \mathrm{l}: 12 \mathrm{~h} \mathrm{D}\right)$ in aerated polypropylene 30-liter terrariums $(70.5 \times 39.5 \times 18.5 \mathrm{~cm})$. The used nominal $\mathrm{Cd}$ concentrations were $0,0.02,0.05$, $0.2,1,10$ and $100 \mathrm{mg} / \mathrm{kg} \mathrm{d}$. wt. with three replicates used per each dose diet. These treatments were abbreviated as $0 \mathrm{Cd}, 0.02 \mathrm{Cd}, 0.05 \mathrm{Cd}, 0.2 \mathrm{Cd}, 1 \mathrm{Cd}, 10 \mathrm{Cd}$ and $100 \mathrm{Cd}$. The rearing method and the corresponding procedures were similar to those used in our previous experiments [1].

After being oven dried at $105^{\circ} \mathrm{C}$, for $24 \mathrm{~h}$, the hepatopancreas samples (between 1.2-1.5 g/ each sample) were weighed (to the nearest $0.01 \mathrm{mg}$ ) with an analytical balance (TP-214, Denver Instrument $\mathrm{GmbH}$ ). Following their calcination in a muffle furnace (Nabertherm B150, Lilienthal) at $550^{\circ} \mathrm{C}$, for $6 \mathrm{~h}$, the ash obtained was dissolved with nitric acid using the wet digestion approach -as previously described for standard processing of animal samples [5].

Finally, the filtrates were brought to $25 \mathrm{~mL}$ using $10 \mathrm{~mL}$ $0.5 \mathrm{~N} \mathrm{HNO}_{3}$ and cadmium concentrations were determined using an atomic absorption spectrometer (Varian AA240FS) fitted with a Cd-specific hollow-cathode lamp as the source of radiation. The results were expressed as $\mathrm{mg} / \mathrm{kg} \mathrm{d}$.wt.

\section{Statistical method}

Differences in hepatopancreas cadmium among were analyzed using a Kruskal Wallis test, with posthoc Dunn's tests being applied in case of significant differences.

\section{Results and discussions}

Land snails (Pulmonata) have several ecological and biological attributes rendering them suitable study system for Cd hazard. These are: (i) ecologically associated with humans (i.e., synanthropic species), and also the most species-rich group of terrestrial mollusks; (ii) concentrate higher amounts of $C d$ than most terrestrial higher bilaterians (including commonly used toxicological models such as rats, mice, earthworms, or arthropods); (iii) sensitive to low level Cd exposure of contamination [6-8].

Cantareus aspersus (syn. Helix aspersa) was used as study system in this present work because it is the most often used terrestrial gastropod in environmental toxicology; it has a well- known biology [9] and is easily reared under laboratory conditions [10].

Commonly used animal models in toxicological studies (e.g. rats, mice, fish) have separate sexes, both of which have to be tested for providing relevant results on cadmium retention dynamics. Land snails, by contrast, are hermaphrodites; therefore, their use is a more costeffective alternative to vertebrate study systems in ecotoxicological studies on cadmium [11]. 
Literature data have shown that these mollusks are easy to grow under controlled laboratory conditions using agar-based feeds $[4,8,12]$. Indeed, the feed used here was well accepted by the test snails. The cadmium levels in feed were: (1) for the $0 \mathrm{Cd}$ treatment, below the detection Threshold $(0.01 \mathrm{mg} / \mathrm{kg} \mathrm{d}$. wt); (2) for the $0.02 \mathrm{Cd}$ treatment, $0.02 \pm 0.01 \mathrm{mg} / \mathrm{kg} \mathrm{d}$. wt; (3) for the $0.05 \mathrm{Cd}$ treatment, $0.05 \pm 0.03 \mathrm{mg} / \mathrm{kg} \mathrm{d}$. wt; (4) for the $0.2 \mathrm{Cd}$ treatment, 0.18 $\pm 0.06 \mathrm{mg} / \mathrm{kg} \mathrm{d}$.wt; (5) for the $1 \mathrm{Cd}$ treatment, $0.98 \pm 0.24$ $\mathrm{mg} / \mathrm{kg} \mathrm{d}$. wt; (6) for the $10 \mathrm{Cd}$ treatment, $9.82 \pm 1.03 \mathrm{mg} /$ $\mathrm{kg} \mathrm{d}$. wt; (7) for the $100 \mathrm{Cd}$ treatment, $99.52 \pm 3.44 \mathrm{mg} / \mathrm{kg}$ d. wt. These doses are environmentally-relevantsince they overlap with the maximum Cd concentrations allowed in vegetal foods, such as leafy vegetables or fruits $[13,14]$.

The median concentrations of $\mathrm{Cd}$ measured in the hepatopancreas were: (1) for the $0 \mathrm{Cd}$ treatment, $2.57 \mathrm{mg} /$ $\mathrm{kg} \mathrm{d}$. wt; (2) for the $0.02 \mathrm{Cd}$ treatment, $3.80 \mathrm{mg} / \mathrm{kg} \mathrm{d}$. wt; (3) for the $0.05 \mathrm{Cd}$ treatment, $4.85 \mathrm{mg} / \mathrm{kg} \mathrm{d}$. wt; (4) for the $0.2 \mathrm{Cd}$ treatment, $4.98 \mathrm{mg} / \mathrm{kg} \mathrm{d}$. wt; (5) for the $1 \mathrm{Cd}$ treatment, $44.34 \mathrm{mg} / \mathrm{kg} \mathrm{d}$. wt; (6) for the $10 \mathrm{Cd}$ treatment, $212.14 \mathrm{mg} / \mathrm{kg} \mathrm{d}$. wt; (7) for the $100 \mathrm{Cd}$ treatment, 406.36 $\mathrm{mg} / \mathrm{kg} \mathrm{d}$. wt. (fig. 1). The measured values in controls were within the same range with those assessed in one of our previous experiments [1], as well as with those determined in specimens sampled from unpolluted areas [ 15,16$]$. The maximum Cd levels observed here are also of interestfrom an ecotoxicological point of view since they are among the highest values ever reported in C. aspersus. Therefore, these values may be used as a benchmark for future studies investigating $\mathrm{Cd}$ retention in this gastropod species.

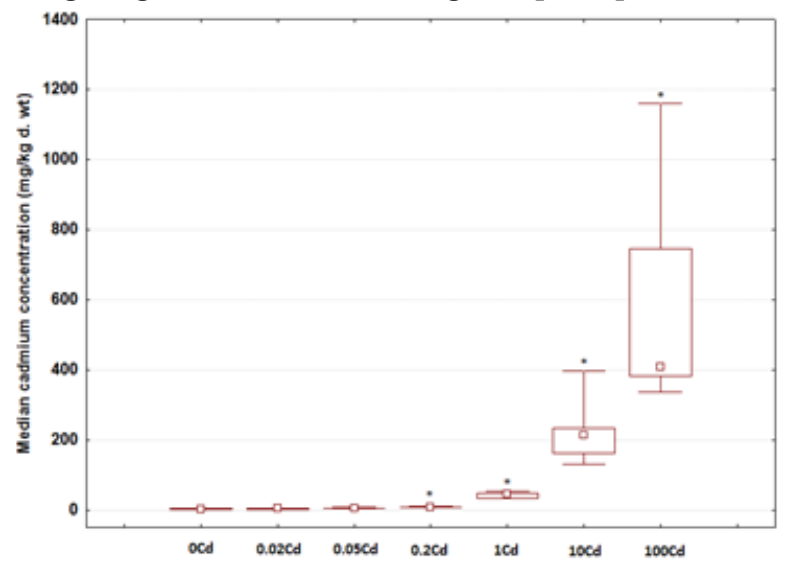

Figure 1. Median $\mathrm{Cd}$ concentrations in the hepatopancreas of Cantareus aspersus snails.Data are shown as medians (point) with lower and upper quartiles (box) and minimum and maximum values (bars). Marked boxes $(*)$ indicate significant differences as compared to the reference group (Dunn test, $*_{-} p<0.05$ ).

Were identified significant differences in hepatopancreas Cd levels (Kruskal-Wallis, $p<0.001$ ).

The measured values increased significantly compared to controls starting from the third $\mathrm{Cd}$ treatment (i.e. $0.2 \mathrm{Cd}$ treatment) onward, as shown by post hoc analyses using Dunn tests (fig. 1). In a previous study, were investigated the retention of $C d$ in adult $C$. aspersus snails at similar exposure doses, but for shorter durations, namely 14, 28 and 56 days. Interestingly, the dose from which significant increases in hepatopancreas $\mathrm{Cd}$ were detected was similar [1].These results suggest the potential existence of threshold level below which these land snails are able to maintain relatively stable cadmium concentrations in the hepatopancreas, which is up to $5 \mathrm{mg} / \mathrm{kg} \mathrm{d}$. wt.

Starting from the third dose onward, the test snails concentrated $\mathrm{Cd}$ not only in a dose dependentmanner, but also at levels far above the measured values in the food. This renders the hepatopancreas of mature snails, $C$. aspersus, as excellent endpoints for assessing $\mathrm{Cd}$ toxicity over a broad range of concentrations. Serving as a barometer for dietary $\mathrm{Cd}$ exposure ${ }^{-}$the main path of $\mathrm{Cd}$ uptake not only in terrestrial gastropods [6], the hepatopancreas of this species of land snails can hence be reliably used for both active and pasive biomonitoring of environmental cadmium pollution.

\section{Conclusions}

The results of the present study support the use of hepatopancreas of mature snails, $C$. aspersus, as endpoints for assessing $\mathrm{Cd}$ accumulation and toxicity over a broad range of concentrations. Therefore, this gastropod species can be reliably used for both active and passive biomonitoring of environmental cadmium pollution.

\section{References}

1.NICA, D. V., POPESCU, C., DRAGHICI, G. A. PloS one, 2017.

2.*** WORLD HEALTH ORGANIZATION (WHO)., Denmark, 2007.

Available from: http://www.euro.who.int/data/assets/pdf_file/0007/ 78649/E91044.pdf.

3.*** AGENCY FOR TOXIC SUBSTANCES AND DISEASE REGISTRY (ATSDR); Atlanta, GA, USA, 2012. Available from: https:// www.atsdr.cdc.gov/toxprofiles/tp5.pdf.

4.LASKOWSKI R, HOPKIN SP. Ecotoxicol Environ Saf. 1996: p 59-69. 5.FAROON, O., ASHIZAWA, A., WRIGHT, S. Toxicological profile for cadmium. 2012. pmid:24049863.

6.de VAUFLEURY A, COEURDASSIER M, PANDARD P. Environ Toxicol Chem. 2006: p 797-806.

7.HODL E, FELDER E, CHABICOVSKY M. Cell Tissue Res. 2010: p 159171.

8.ITZIOU A, DIMITRIADIS V. Sci Total Environ. 2011: p 1181-1192.

9.DALLINGER R, BERGER B, TRIEBSKORN R, Kohler $\mathrm{H}$. The biology of terrestrial molluscs. CAB International, Oxon, 2001: p 489-525.

10.NICA, D. V., BORDEAN, D. M., PET, I. (2013). Chemistry Central J ournal.

11.NICA, D., POPESCU, C., DRAGHICl, G. Environmental Science and Pollution Research. 2017: p 15187-15195.

12.BERGER, B., DALLINGER, R., FELDER, E. Ecotoxicology of metals in invertebrates, 1993: $p$ 291-313.

13.*** MWFEP. Ordinul nr. 756/1997 al Ministerului Apelor, Padurilor si Protectiei Mediului pentru aprobarea Reglementarii privind evaluarea poluarii mediului modificat de Ordinul nr. 1144/2002 al Ministerului Apelor si Protectiei Mediului, 2002.

14.***Comission European. Regulation (EC) No 1881/2006 of 19 December 2006 setting maximum levels for certain contaminants in foodstuffs. Official J ournal of the European Union, L Series. 2006;364: $5-24$.

15.MENTA C, PARISI V. Environ Pollut. 2001: p 205-208.

16.BEEBY A, RICHMOND L. Ecol Indic. 2002

$\overline{\text { Manuscript received: } 10.01 .2019}$ 